\title{
Connected education and the co-construction of knowledge in a joint course for law and interpreting students
}

\author{
Mira Kadrić \\ University of Vienna \\ mira.kadric-scheiber@univie.ac.at \\ http://orcid.org/0000-0001-6152-6661 \\ Sylvi Rennert \\ University of Vienna \\ sylvi.rennert@univie.ac.at \\ https://orcid.org/0000-0003-2425-8658 \\ Dalibor Mikić \\ University of Vienna \\ dalibor.mikic@univie.ac.at
}

\begin{abstract}
This article raises questions of education sociology with a focus on one of its core concepts: connectedness. It relates the dimensions of the connected curriculum to research on didactic approaches, showing how methods of connected learning and the co-construction of knowledge can be applied at different levels to enable students to gain subject-related, methodological and transdisciplinary communicative competence in addition to building relationships and cooperation among them across fields of study. These dimensions are presented using the example of the course "Questioning techniques from the perspective of criminology and interpreting". During this course, students of law and interpreting had the opportunity to acquire both core theoretical knowledge of and practical experience in questioning techniques. This they did through role playing the questioning of defendants and witnesses that typically occurs in a courtroom from the perspective of both criminology and interpreting. The evaluation and feedback showed that the law and the interpreting students appreciated the way the course made them aware of issues in both their own and the other field, helped them to connect academic learning to professional competences and gave them insights into interprofessional cooperation in interpreted legal settings.
\end{abstract}

Keywords: connectedness, connected learning, questioning techniques, legal interpreting

\section{Legal interpreting and perspectives on connected education}

Interpreting competence is based on language and cultural competence and encompasses the cognitive and emotional processing of information in the fields relevant to interpreting. $A$ 
Kadrić, M., Rennert, S., \& Mikić, D. (2021). Connected education and co-construction of knowledge in a joint course for law and interpreting students. Linguistica Antverpiensia, New Series: Themes in Translation Studies, 20, 52-73.

key aspect of interpreter education is that students are not simply prepared for a concrete profession but given fundamental and specific technical and methodical competencies that allow them to work in different areas of interpreting (cf. Hale \& Gonzalez, 2017; Kadrić, 2017; Kelly, 2010; Skaaden, 2013). The goal is to enable graduates to work in specific areas as well as in contexts that encompass several areas, always guided by their reflection on research. The foundation for this is connectedness in both the social and the technical contexts.

\subsection{Connectedness in higher education}

Connectedness has become a key concept in higher education. Barnett (2016) speaks of twelve dimensions of connectedness as being an intrinsic part of higher education, including connections between disciplines, between research and teaching, between theory and practice and between academia and the wider society. Building on Barnett's work, Fung (2017) identifies six dimensions of a Connected Curriculum, which is built around the overarching idea of "learning through research and enquiry". It involves students making connections with other students throughout their programme of study and with researchers, across subjects and out into the world; it also entails participating in academic and workplace learning and acquiring the competence to produce outputs directed at an audience.

By doing so, students are encouraged to look at a problem from different perspectives, on the one hand, and to see their own discipline in a larger context, on the other - making them more globally and ethically aware of the world around them. Possible examples for interpreting programmes include transdisciplinary courses. Other similar approaches could also be used outside higher education in interprofessional training (for an overview, see Rennert, 2021) or in mixed settings. An example of a mixed setting would be professional interpreters who are seeking to specialise in healthcare interpreting learning together with medical students, as described by Bansal et al. (2014).

Against this backdrop, students are also expected to "engage in critical dialogue with others about the evidence-based application of knowledge to society" (Fung, 2017, p. 7). This ties in with the concept of situated learning, where the emphasis is not on the rote learning of content but on understanding, reflecting on and applying it in context. This is achieved through a collaborative process as part of a community. Situated learning models have also been applied in interpreter training, using both real and simulated working environments (e.g., Crezee, 2015; González-Davies \& Enríquez-Raído, 2016; Prieto-Velasco \& FuentesLuque, 2016).

\subsection{Connectedness and situated learning: the example of criminology and legal interpreting}

A major goal of the course described in this article was to help students from two different disciplines to build a community of practice through shared activities, methods, relationships and new experiences. As important elements of interpreted criminal proceedings, the course "Questioning techniques from the perspective of criminology and interpreting" $i$ was held jointly for students of interpreting and law. The disciplines of criminology and interpreting 
Kadrić, M., Rennert, S., \& Mikić, D. (2021). Connected education and co-construction of knowledge in a joint course for law and interpreting students. Linguistica Antverpiensia, New Series: Themes in Translation Studies, 20, 52-73.

have a lot in common, not only in their practical application in the courtroom but also in their transdisciplinary nature.

Criminology as a fundamentally transdisciplinary discipline draws on different fields, especially law, sociology and psychology, always relating them to crime (Grafl \& Stempkowski, 2017; Walklate, 2007). It combines normative criminal law and empirical research to investigate crime itself - its causes, effects and patterns of behaviour - from the perspectives of psychology and the social sciences.

One of the most important criminological methods of gathering information is questioning. Questioning suspects or witnesses, for instance, is a key part of collecting evidence, which the authorities and courts use to make findings and take decisions. Questioning techniques are therefore of great importance. Both jurisprudence and criminology are closely concerned with questioning, albeit from different perspectives and emphasising different aspects.

The main objective of questioning is always to gather information and clarify facts. The competent authorities, such as the public prosecutor's office or the court, evaluate its outcome. Authorities and courts regularly have to assess whether they consider a statement to be true or false. This is necessary because different people often give different information on the same matter - either because subjectively they perceive it differently or because they deliberately give false information to avoid punishment or to further their own interests (cf. Stempkowski \& Grafl, 2021). When evaluating statements, the authorities and courts assess all the information provided, including all the relevant verbal and nonverbal elements. The verbal content refers to all the linguistic elements of speech. Nonverbal communication includes gestures and facial expressions, voice volume, pauses or silences, intonation, posture, spatial behaviour, etc. (cf. Ahrens, 2015; Argyle, 2013; Artkämper \& Schilling, 2014). And it is precisely for this assessment of which statements are true and which are untrue that criminology, through its insights into the practice of criminal law, provides essential tools. There are a number of criminological research studies on the question of how best to qualify statements (see, for example, The Global Deception Research Team, 2006). Based on their results, criminologists have developed questioning and analysis techniques (cf. Vrij, 2005; Vrij \& Mann, 2006).

The use of an interpreter when questioning someone changes the setting considerably. Criminological research shows that the presence of an interpreter sometimes makes it easier to assess the truth of a statement, and sometimes harder. It can make it easier in that the person conducting the questioning hears the statement twice, which allows them to concentrate on nonverbal cues while listening to the statement of the interviewee and to focus on its content during the rendition provided by the interpreter (Leins et al., 2017). On the other hand, a study by Vrij et al. (2018) shows that liars showed fewer cues of deceit when being interpreted - possibly for the same reason - therefore complicating the process of detecting deception.

The goal of interpreting is to establish the best possible communication. As in any other setting, legal interpreting requires an understanding of the communication strategies at work - in this case, the discourse and questioning strategies in legal proceedings (cf. Berk-Seligson, 
Kadrić, M., Rennert, S., \& Mikić, D. (2021). Connected education and co-construction of knowledge in a joint course for law and interpreting students. Linguistica Antverpiensia, New Series: Themes in Translation Studies, 20, 52-73.

1990/2017) based on criminology and psychology rather than merely on a basic understanding of law and legal terminology.

In a discussion of interpreting strategies in legal settings, it is essential first to distinguish between the strategies of preserved (also referred to as verbatim or literal) and customised (also referred to as instrumental or liberal) interpretingii as a functional-pragmatic approach to decisions on the way to interpret in specific settings. Among other factors, this depends on whether the purpose of interpreting in a given situation is to take evidence or to facilitate communication in an extra-evidentiary setting. Evidentiary interpreting requires a much higher degree of precision than extra-evidentiary interpreting, the interpreter having to preserve both the form and content of the original statement as closely as possible - up to and including the grammatical structure, unusual word choices, hesitations, pauses and selfcorrections, as they may be of relevance to the person conducting the questioning (Kadrić, 2019).

The importance of pragmatic equivalence and a functional interpretation is indicated in a number of studies, including seminal works by Berk-Seligson (1990/2017), Hale and Gibbons (1999), Rigney (1999), Hale (2001, 2004), Jacobsen (2004) and Kadrić (2019). These studies consider the way in which omissions and additions by the interpreter can change the semantic and/or pragmatic content of the original message and how, for instance, the omission of modal verbs and the restructuring of coercive task questions into less restrictive yes/no questions can change response behaviour and affect the questioning strategy, which often relies on very deliberately worded questions.

It is worth noting that questioning techniques are discussed in some publications in the field of interpreting studies, such as the empirical study by Lai and Mulayim (2014). Their study illustrates the influence that the interpreter's choice of words can have on the questioning strategy of police officers: they note that it makes a difference whether the interpreter says "how come" or "why", although at first glance they differ only in the smallest of nuances. However, many questions regarding interpreter-mediated questioning remain unanswered, such as comparisons of the amount of detail between interpreter-mediated questioning and questionings conducted in native languages (cf. Vrij et al., 2018). It is also unclear if the interpreting process is influenced in any way by whether the interpreter believes the interviewee to be telling the truth or lying. To date, there has been no research on the effect of the interpreter's opinion regarding the innocence or guilt of the accused on the interpreting process (Evans et al., 2020).

All of these questions are of interest to both of the disciplines of criminology and legal interpreting studies. Transdisciplinary exchange is enabled by connected curricula, joint research projects and joint training both at university and as continuing education, such as further training for legal interpreters and legal professionals.

\section{Learning through research and enquiry}

One of the most important responsibilities of universities, in addition to research, is to provide teaching of the highest quality and to continue to develop it further. Changes in the discipline, 
Kadrić, M., Rennert, S., \& Mikić, D. (2021). Connected education and co-construction of knowledge in a joint course for law and interpreting students. Linguistica Antverpiensia, New Series: Themes in Translation Studies, 20, 52-73.

connected domains and society should be reflected in the way teaching is organised, the manner in which knowledge in the field is imparted, and in the degree of transdisciplinarity of the subject. These changes bring about not only challenges but also new opportunities for developing and expanding the subject areas. In this article, we discuss the ways in which the different forms of learning were applied in a joint course for interpreting and law students by investigating both the interaction and the use of language by means of video recordings of questioning and interpreting scenarios acted out in class, reflection and discussion, observation notes and retrospective feedback via a questionnaire.iii

\subsection{Joint teaching, joint learning: Questioning techniques from the perspective of criminology and interpreting}

The course "Questioning techniques from the perspective of criminology and interpreting" was organised jointly in the winter term 2018/2019 at the University of Vienna by two institutes from two departments - the Institute for Criminal Law and Criminology and Institute for Translation Studies. It was intended for students of law and interpreting, giving them the opportunity to acquire both theoretical knowledge of and practical experience with questioning techniques from the perspectives of criminology and interpreting studies. The course was held at the Faculty of Law, which mirrors the way interpreters enter the work environment of legal professionals when they collaborate with them.

The course was held as preparation for the pilot project, Transcultural Law Clinic, which was developed in the context of the DG Justice project TransLaw ${ }^{i v}$ and held the following year. The aim of the transdisciplinary project "TransLaw - Exploring Legal Interpreting Service Paths and Transcultural Law Clinics for persons suspected or accused of crime" was to study and improve interpreting in legal settings for persons suspected or accused of crime. Developing Transcultural Law Clinics at the participating universities (KU Leuven, Maribor, Trieste, Vienna) where law and interpreting students could learn together and from each other as well as holding joint training sessions for interpreters and legal professionals were additional key elements of the project.

The course on questioning techniques allowed the Vienna research team to gain valuable experiences with and insights into connected learning at the intersection of criminology and interpreting that would influence the design of the Vienna Transcultural Law Clinic.

The course had two instructors: a professor of interpreting studies and translation didactics with extensive experience as a court interpreter and a professor of criminology who had often served as an expert witness in criminological matters. The course had 18 participants: 10 law students and 8 interpreting students with the working languages Arabic, Bosnian/Croatian/Serbian, English, German, Romanian and Spanish. The law students were interested in becoming judges or public prosecutors, while the interpreting students mostly wanted to become court interpreters. Furthermore, a postdoctoral researcher with more than a decade of experience as an interpreter attended as a non-participating observer. 
Kadrić, M., Rennert, S., \& Mikić, D. (2021). Connected education and co-construction of knowledge in a joint course for law and interpreting students. Linguistica Antverpiensia, New Series: Themes in Translation Studies, 20, 52-73.

\subsection{Didactic approach}

The course "Questioning techniques from the perspective of criminology and interpreting" used a comprehensive transdisciplinary approach that involved both domains equally, gathered and discussed questions from both domains and prompted students to reflect on interdependencies between the professions as well as the broader institutional context. It combined subject-related input, written assignments, discussions, analysis, role-play and retrospective feedback. In this article, we focus primarily on the role-play, the subsequent analysis and discussions, and the feedback questionnaire results.

The course used a didactic approach that attempted to activate all of the elements of the pyramid shown in Figure 1. It relates the dimensions of the connected curriculum to research on didactic approaches, showing how methods of connected learning and the co-construction of knowledge can be applied at different levels to enable students to acquire subject-related, methodological and transdisciplinary communicative competence, and also to build relationships and cooperation with students across fields of study. It is based particularly on critical-constructive didactics (cf. Kadrić, 2011, building on Klafki, 2007 and Ott, 2011). Each of the four elements is connected to and dependent on the others.

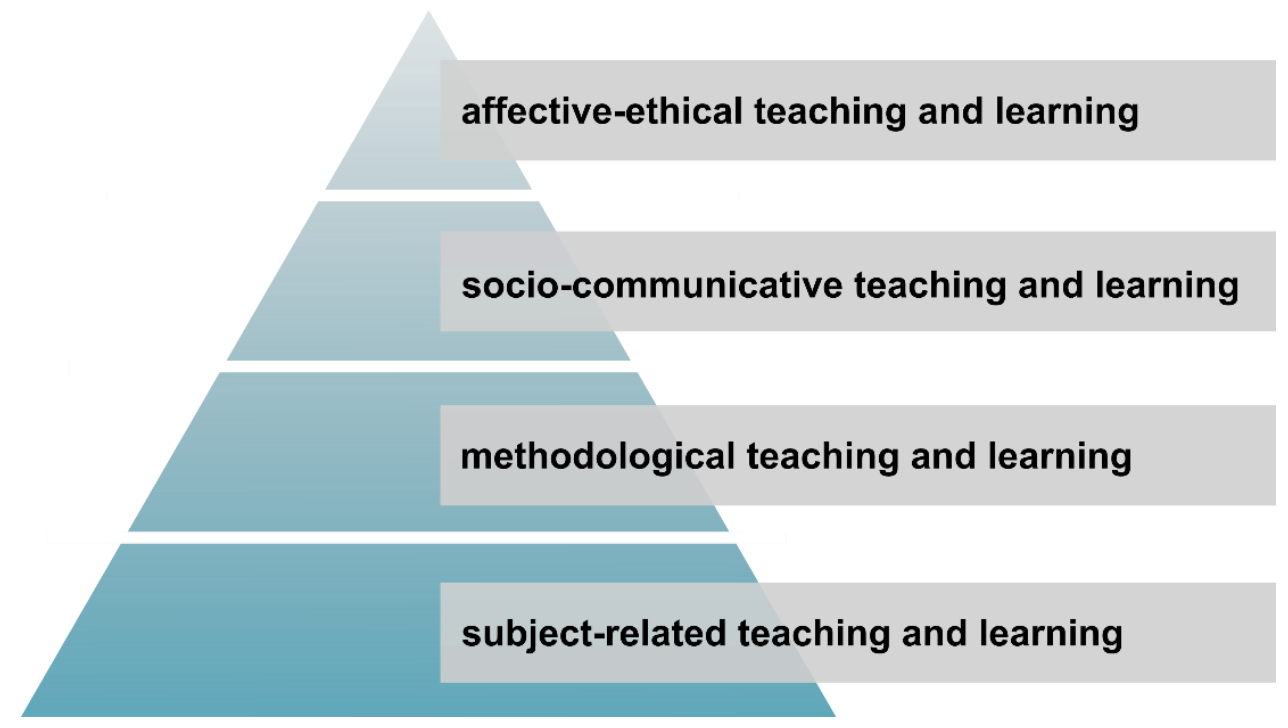

Figure 1: Dimensions of connected learning

The foundation of material education is subject-related teaching and learning, which refers mainly to factual knowledge. Subject-related teaching and learning determines the content not only the subject-matter that will be taught but also the questions students will have to reflect on in order to become confident, equal partners with others as postulated by emancipatory didactics. Intention, therefore, is the foundation for selecting and balancing course content, which is fundamental to an understanding of the subject, is of current and future relevance and serves to illustrate examples.

Methodological-operative teaching and learning refers to the competencies and skills in applying acquired knowledge. It encompasses the principles of acting in the field, the techniques and tools used and the action space in which we operate, which operationalise 
Kadrić, M., Rennert, S., \& Mikić, D. (2021). Connected education and co-construction of knowledge in a joint course for law and interpreting students. Linguistica Antverpiensia, New Series: Themes in Translation Studies, 20, 52-73.

the learned content. They allow targeted action based on the principles of the subject-matter. The methodological approach is always structured, but its content varies depending on the situation.

Cultures of teaching and learning influence the way we acquire content- and method-related knowledge in addition to the concepts and ideas we develop in our minds. Where different teaching and learning cultures meet, those concepts and ideas may collide. The following two approaches centre the (re)shaping of teaching and learning cultures while taking into account different individual subject-related processes and attempts to consider potential differences in social, cultural and societal processes.

Socio-communicative teaching and learning teaches transdisciplinary teamwork and cooperation by using methods suited to students, in the process developing a deeper understanding of the (other) subject and how to work with it.

Finally, affective-ethical teaching and learning approaches the subject-matter being taught not in a purely factual manner but with a focus on reflection, interaction and communication.

Including the two approaches at the top of the pyramid paves the way for successful cooperation and mutual trust and support. Although joint teaching and learning communities are often formed temporarily, they are characterised by a certain recursiveness - in a joint effort, actions and structures are mutually dependent on each other. The structures determine and facilitate action and are, in turn, influenced and shaped by the action and the persons involved in it.

\section{Perspectives on co-construction of knowledge}

The content of the course, from the domains of both law and interpreting studies, was mostly new for all the students - in contrast to other interdisciplinary education concepts, where students learn about another subject and build on the knowledge they already have in their own field. In the course discussed here, however, the legal-criminological content was also new for the students of law, and the students of interpreting studies were not familiar with the interpreting-related content conveyed.

\subsection{Subject-related approach}

The joint course took a holistic approach, combining two subject areas into one cohesive whole.

The subject-related input started with the criminological and legal foundations of questioning in criminal proceedings, taking Austrian law as its legal basis. First, the importance of questioning to gathering information and evidence was explained. Next, the questioning process itself was discussed in detail. This included explaining the many similarities and the differences in the questioning of suspects or defendants and of witnesses, such as the setting, questioning techniques and assessing the veracity of a statement. A core difference that was highlighted is that suspects and defendants are not legally obliged to testify truthfully. It is important to be aware that leading questions, deception and threats are prohibited by 
Kadrić, M., Rennert, S., \& Mikić, D. (2021). Connected education and co-construction of knowledge in a joint course for law and interpreting students. Linguistica Antverpiensia, New Series: Themes in Translation Studies, 20, 52-73.

Austrian law. The individual phases of questioning were discussed in detail: preparation, the summons to the suspect or witness, conducting the questioning and the important question of recording statements. In this regard, the attention of law students was drawn to the fact that interpreters usually take notes for consecutive interpreting but that interpreting notes cannot replace a courtroom stenographer's notes, as their scope and purpose are different.

In this context, the role of memorising information was discussed, both with regard to attention and processing capacity and regarding the importance of the original utterance. In legal settings, in particular, the tiniest nuances of meaning can be of great importance.

Processing capacity is a finite resource, as described by Gile (2009). ${ }^{\vee}$ Writing notes in the target language requires more processing capacity than in the source language (Gile, 2009, pp. 182-183). Therefore, it makes sense for learners to write down information that needs a great deal of processing capacity in the source language. The approach of recording information in the source language can be found as early as Herbert (1968) as part of learning intralingual note-taking as a first step. Being able to render a text in the same language completely, correctly and in adequate words is a fundamental requirement of consecutive interpreting. By taking any notes that are not language-independent in the source language, the notes become a material memory of the main elements the interpreter heard rather than their possible counterparts in the target language. They become, in a way, a record of what was said that can be used not only for the immediate rendition in the target language but also for any back translations, questions or comparisons of what was said to the information recorded in the official minutes. This record could become important, for example, in case of a misunderstanding arising or if the person being interpreted claims they said something else in the original. This was new even to some of the interpreting students.

The question of interpreting is of both legal and factual relevance to the way the questioning is conducted. Both witnesses and persons suspected or accused of having committed a crime who do not have sufficient command of the language of the criminal proceedings are interviewed with the assistance of an interpreter; however, persons suspected and accused of a crime have more extensive rights to communicative assistance. For example, they are entitled to the assistance of an interpreter free of charge when communicating with their legal counsel. This right has for some time been enshrined in European law. The right to legal counsel was also discussed during the course: the right to a defence counsel does not exist in Austria for all criminal proceedings; the right is available only for offences of a certain severity or in special circumstances, such as the imposition of pre-trial detention.

Following the professors' input, the significance of the communicative setting to criminology was discussed, that is, the environment, the person conducting the questioning and the questioning technique. The influence of language, facial expressions and gestures on communication was discussed, and students heard about scientific experiments on the socalled 'anchoring effect' and the 'framing effect' (Artkämper \& Schilling, 2014, pp. 84-88). An important criminological topic in the course was the assessment of the credibility of the person being questioned (cf. Grafl \& Stempkowski, 2017). The students learned about key research results in the field, such as nonverbal signals that can indicate lies (e.g. widening pupils, a change in voice pitch, facial expressions). However, they were also made aware that 
Kadrić, M., Rennert, S., \& Mikić, D. (2021). Connected education and co-construction of knowledge in a joint course for law and interpreting students. Linguistica Antverpiensia, New Series: Themes in Translation Studies, 20, 52-73.

there are no scientifically confirmed sure signs of lying, and researchers therefore recommend considering both the verbal and the nonverbal clues closely (e.g., Artkämper \& Schilling, 2014, pp. 40-44; Luciew et al., 2011; Vrij, 2006).

Of particular interest to both student groups was a guest lecture by a defence lawyer who works internationally and is a professor at an Austrian university, where he has set up a law clinic. He informed the students about the view of the defence counsel and the perspective of those being questioned. He was also one of the defence lawyers in a court case that is an example of a situation where the interpreter's competence and diligence had a decisive impact on the outcome of the trial: an Italian citizen was being tried for armed robbery and the murder of a jeweller in a high-profile case in Austria. He had already been tried - and acquitted - in Italy; as a result, there was a large volume of evidence from Italy, and an Italian police officer who had been in charge of monitoring and transcribing the defendant's phone calls was called as a witness. In one of the phone calls, the defendant had, in the police officer's opinion, confirmed his guilt by replying "so ben io" to his conversation partner's comment about matters pertaining to the murder. In standard Italian, "so ben io" means "I know exactly". However, upon the defendant's insistence that he had meant the opposite, the interpreter was asked whether that could be true. Although she did not know the answer, she offered to find out, and was able to confirm with an expert at the University of Bologna, that in the local dialect, which the defendant spoke, "so ben io" meant the opposite, "I have no idea". As the entire conversation had been held in the Bolognese dialect, and the police officer listening to it was from Rome, this meaning had escaped him.

The input on criminology and criminal law served as the basis for the subsequent input on interpreting. The students were introduced to the basics of interpreting, especially on what functional and successful communication entails. In this regard, the two terms preserved and customised interpreting were covered in detail, which prompted a lively discussion between the professors and students of both disciplines. For the law students this was new information, as they were convinced that interpreters had to translate everything "word for word". They initially rejected the notion of interpreters making changes of their own accord, arguing that the interviewers would probably lose control over the questioning situation were they to make changes. It was then illustrated by means of an example what customising actually means. The students were asked if they knew the meaning of a typical legal phrase used in Austrian courtrooms: "Sie können von Ihrem Entschlagungsrecht Gebrauch machen." ("You may use your right to remain silent.") Entschlagungsrecht is a highly specialised Austrian legal term, which derives from Middle High German and which even many native speakers do not understand. The more generally comprehensible way of wording this caution would be "Recht, die Aussage zu verweigern", which has the same meaning but uses more general language. ${ }^{\text {vi }}$ Most of the law students knew the meaning; many interpreting students did not. The law students were then asked if they could explain the phrase in plain German to their peers. As everybody in the classroom finally learned the meaning, the students understood that using a plain language term instead of the specialised one neither necessarily changed the content nor the intent of the speaker, but instead ensured that the communicative goal - that is, comprehension, - was attained. 
Kadrić, M., Rennert, S., \& Mikić, D. (2021). Connected education and co-construction of knowledge in a joint course for law and interpreting students. Linguistica Antverpiensia, New Series: Themes in Translation Studies, 20, 52-73.

At the same time, it was also made clear that in some situations preserved interpretation is the only appropriate approach for interpreters - for example, when interpreting statements from defendants and witnesses. In such cases, all nuances, false starts, awkward expressions and the like should be conveyed precisely in the target language. Doing so enables legal professionals to draw genuine conclusions about the veracity of a testimony.

\subsection{Methodological-operative approach}

Methodological-operative teaching and learning develops and strengthens the skills and competencies necessary to applying knowledge. Transdisciplinary work is based on relationships and mutual learning. Some established examples of this are tandem learning, role-play and simulations. All three forms of pedagogical interaction are suited for practising work with content, texts, situations, persons, intentions and emotions (Kadrić, 2015, pp. 360361).

During the semester, the students had to complete a number of assignments on their own, in pairs and in groups. The law students each developed a short questioning scenario (police interview or trial) and provided a glossary of five to seven relevant terms in German with legal definitions and explanations in general language. The interpreting students researched this terminology in their other working language. Those with the same working languages then worked in tandem to correct each other's glossaries. The glossaries were used as preparation for short role-plays in class based on the questioning scenarios.

In class, the students worked as a team to prepare the scenarios, deciding on chair and table placement and allocating seats. In the penultimate class of the semester the students worked together to develop a scenario for the final simulation, to allocate the roles of defendants, defence counsel, witnesses, judges, public prosecutor and interpreters, and to decide who would speak which language. The law student playing the role of the public prosecutor drafted the indictment. Inspired by the defence counsel's guest lecture, the students chose as their scenario an armed robbery of a jeweller's with an associated murder.

The questioning scenario was prepared based on the so-called PEACE model as a basis for an effective questioning strategy. This five-step model consists of the phases planning and preparation, engage and explain, account, closure and evaluate (Soukara et al., 2009).

The roles included one presiding and two associate judges (played by law students), a prosecutor (law student), three defendants (two of whom did not understand the language of the court, played by law and interpreting students), four witnesses (one of whom did not understand the language of the court, played by law and interpreting students), four interpreters (two interpreters for Arabic taking turns, one for Bosnian/Croatian/Serbian, one for Romanian) and one expert witness (played by the professor of criminology).

The simulated trial took nearly three hours, including short breaks. It was recorded on video and the students transcribed the entire trial, with the law students transcribing the German parts and the interpreting students transcribing the interpretations and translating them back into German. This shared transcription was the basis for the students' final reports. 
Kadrić, M., Rennert, S., \& Mikić, D. (2021). Connected education and co-construction of knowledge in a joint course for law and interpreting students. Linguistica Antverpiensia, New Series: Themes in Translation Studies, 20, 52-73.

\subsection{Socio-communicative approach}

Socio-communicative teaching and learning involves teamwork and cooperation, especially through the teaching methods chosen. Both criminology and interpreting studies start from the premise that human beings communicate holistically, using both visual and acoustic signals. These signals differ depending on a person's personality and the character of the communicative event. The nonverbal signals are an indispensable part of communication and may, at times, be more important than the verbal expression: we always say more than we express in words.

The role-play scenarios were conducted using the technique forum theatre (Boal, 1993; Kadrić 2011; Kadrić, 2014a) and consisted of the following learning and feedback steps: reflection $\rightarrow$ improvising $\rightarrow$ trying out solutions $\rightarrow$ another reflection phase $\rightarrow$ action. The order of questioning recommended by the PEACE model (Soukara et al., 2009, pp. 495-496) includes open questions that encourage the subject to describe the events in their own words. This allows the person conducting the questioning to point out discrepancies and contradictions in statements and to then present the evidence. The statement can then be put into question form based on the evidence and contradictions that may have occurred.

The first short role-played questioning scenario brought with it new insights for both student groups. An experience that particularly impressed the law students was that seemingly easy questions in everyday language can be more difficult to interpret than technical language. Terminology was rarely a problem for the interpreting students throughout the course, as they had previous experience with specialised terminology and knew how to prepare for assignments involving technical language. In fact, assumptions posed a bigger problem. An example was a question the "judge" asked the Arabic-speaking "defendant": "Did you see that the men [plain-clothes police officers] had something around their neck?" The "interpreter" asked for clarification of the fragment "having something around the neck", which surprised the "judge". It turned out that the law students expected words of Latin and Greek origin to pose the greatest difficulty for interpreters.

One law student, who planned to become a public prosecutor, had included the term "molecular genetic test" in the glossary for his scenario because he assumed it would be particularly difficult to interpret. However, the interpreting students (especially those whose second language was German, but also students from Germany) found realia, institutional knowledge (e.g. knowing that police officers carry their badge around their neck), regional expressions and (Viennese) dialect more difficult than technical terminology, which they had prepared for.

During the trial, a shared action space ${ }^{\text {vii }}$ with multidimensional alignments emerged in which the "interpreters" and the "legal professionals" moved together and provided mutual assistance. Here we see examples of participant alignment and interaction management (cf. Llewellyn-Jones \& Lee, 2014). Interaction management refers to coordination in the production phase, that is, during the questioning or interpretation, while participant-aligned actions take into account the needs of all participants, including the interpreters. 
Kadrić, M., Rennert, S., \& Mikić, D. (2021). Connected education and co-construction of knowledge in a joint course for law and interpreting students. Linguistica Antverpiensia, New Series: Themes in Translation Studies, 20, 52-73.

The following example demonstrates participant alignment. The "judge" is confirming the "defendant's" name but the name is different from that in his documents.

J Das dürfte ein Fehler gewesen sein.

That must be a mistake.

I

ممكن يكون في خطأ بال..بالكتا

Möglicherweise liegt ein Fehler in der Schreibweise v.

It might have been a spelling mistake.

J Wie war der Nachname nochmal?

What was the surname again?

I

اه اسم العائلة أو الكنية لو سمحت مرة تانية؟

Ah ... Der Familienname bitte noch einmal.

Ah ... the surname once more, please.

D

Al Hashimi

Al Hashimi

I Buchstabieren?

Spell it?

J Nein, danke.

No, thank you.

The video recording shows the "judge" taking notes as the "interpreter" says the correct name. The "interpreter" offers to spell it for him without being asked. Although the "judge" is focused on his notes, it is immediately clear to him that "Spell it?" is not part of the interpretation but rather a question directed at him by the interpreter.

The interpreting students also corrected themselves when they made mistakes. In one case, the "interpreter" raised his hand to interrupt the "defendant". Then he looked at the "judge", corrected his mistake with the words "I as the interpreter" and looked back down at his notes to continue interpreting.

In the final simulation, there were several examples of interaction management from the "presiding judge". As there were three "defendants", two of whom needed to be interpreted (into Arabic and Romanian), the proceedings with consecutive interpreting were quite lengthy. After some time, the "judge" asked the interpreters to use chuchotage with their "defendants". In response, the Romanian "interpreter" started whispering, but the Arabic interpreter did not notice and continued to take notes. The "judge", upon noticing this, asked the Arabic-speaking defendant whether he had been able to follow the proceedings. 
Kadrić, M., Rennert, S., \& Mikić, D. (2021). Connected education and co-construction of knowledge in a joint course for law and interpreting students. Linguistica Antverpiensia, New Series: Themes in Translation Studies, 20, 52-73.

12 (Arabic)

Ich habe alles notiert und jetzt werde ich das dolmetschen.

I have noted it all down and I will interpret it now.

J

Wäre das möglich, das äh im Folgenden dann simultan zu machen? Geht das, oder?

Would it be possible to, ah, interpret simultaneously afterwards? That's possible, right?

12 (Arabic)

Ja.

Yes.

J

Ok. Schön dann lassen wir das erst mal übersetzen.

Ok. Fine then let's have this translated first.

This example also showed how the students were able to use the knowledge they had acquired during the semester both in the simulation and its analysis. However, at this point, several important phases of the trial had already gone by without chuchotage, and one of the "interpreters" did not realise the "judge" had directed his words to both "interpreters", making him unsure of what he should do. In the analysis, the students said the request for chuchotage should have been made earlier in the trial and directed at both "interpreters".

In their analyses, the students emphasised the importance of the note-taking techniques they had acquired. They were able to see the value of taking notes in the source language, as they were able to refer to their notes whenever anything was unclear or there was a misunderstanding and verify the meaning of the words as they had been said in the source language. The law students, in turn, appreciated that the interpreters were able to interpret long segments and use chuchotage during the simulated trial.

In the discussion of the simulated trial, students often referred to the importance of the information they had received about nonverbal communication. The analysis showed how important it was for interpreters to limit their communication to a service and to keep their own nonverbal communication in check (including seating position and equal distance between judge and defendant, neutral clothing, gestures, facial expressions, tone of voice, etc.). They also noted that using notepads had the additional effect of creating distance between the primary communicators and making the interpreter's position clearly visible.

The students also discussed nonverbal communication from the perspective of the recipient of the interpretation. In their analyses, they noted that using an interpreter meant that they first saw the body language of the "defendant" and then received the verbal content of their statement with a delay when the interpretation followed. They had noticed that if they did not understand the source language, they focused more on body language and other nonverbal elements. Compared to a questioning situation without an interpreter, this meant that they were not able to perceive the body language and the verbal message at the same time and draw conclusions from that, which made a difference, particularly for the "judges". 
Kadrić, M., Rennert, S., \& Mikić, D. (2021). Connected education and co-construction of knowledge in a joint course for law and interpreting students. Linguistica Antverpiensia, New Series: Themes in Translation Studies, 20, 52-73.

\subsection{Affective-ethical approach}

Affective-ethical teaching and learning means that topics are treated in a way that is suited to communication and interaction. The latter aspect strengthens cooperation and loyalty within the group, automates the application of the things they have learned, and creates transparency and lasting effects. viii The aim was to enable the law students to assess the veracity of statements from a criminological viewpoint, to conduct questioning and to understand the fundamental approaches of interpreting, perceiving interpreters not merely as assistants to legal professionals but as professionals in their own right.

In their discussion of the simulation, students from both groups often referred to things they had learned earlier in the course. The law students emphasised that they had focused more on nonverbal cues, citing examples such as changes in tone of voice, delay in answering, a reduction in nodding and fidgeting with their feet or, in one case, the wild gesturing of a "defendant". They also said they had deliberately maintained eye contact while the statements were being given and asked unexpected questions.

The students' behaviour and interactions changed throughout the course. In the first roleplayed scenarios, the students mostly focused on their own actions and had no clear idea of the expectations the students from the other discipline had of them or the part they were playing. For example, they were initially barely aware of the importance of nonverbal communication to assessing the veracity of a statement. The law students conducting the questioning focused on wording their questions and looking at their notes rather than at the gestures or facial expressions of those they were questioning. Some of the interpreting students, on the other hand, maintained almost constant eye contact with those being questioned, allowing themselves to be drawn into short conversations with them, relegating the students playing the parts of judges or police officers almost to the role of observers.

In the final simulation, both student groups acted confidently: interpreters asked clarifying questions when necessary, immediately informed the judges of the content of any brief dialogue with a defendant - such as asking questions - and moved to a different seat when this was necessary to interpret better. The law students, on the other hand, were aware of the possibilities of interpreting, with one student who played the part of a judge expressly requesting the interpreters to use chuchotage to save time. Over the course of a semester, aspiring interpreters and criminologists jointly acquired strategies that might help them manage divergent interests in a satisfactory manner in interpreted legal proceedings.

\section{Discussion of results - discourse and exchange}

The interaction between interpreters and the other persons involved is crucial to the success of questioning. Since the 1990s, the active involvement of interpreters in the interaction has been the subject of numerous publications in interpreting studies (for an overview, refer to Kadrić, 2014a, 2014b). Criminological research shows that, for various reasons, the amount of detail provided by subjects in their source-language statements is lower when an interpreter is present than when statements are made in the person's native language without the intervention of an interpreter (Ewens et al., 2017). Other studies have shown that 
Kadrić, M., Rennert, S., \& Mikić, D. (2021). Connected education and co-construction of knowledge in a joint course for law and interpreting students. Linguistica Antverpiensia, New Series: Themes in Translation Studies, 20, 52-73.

the reason for the detailed information not being included in the interpreted statements was that it was not rendered by the interpreters (Vrij et al., 2019). Therefore, it is especially important for interpreters to be familiar with questioning techniques and to be able to recognise questioning strategies and to preserve their style and effect in their interpreting, as findings in interpreting research (cf. Hale et al., 2019) have indicated.

In this exercise, it became apparent that there were many aspects of the interpreting profession that law students were not familiar with. Therefore, both the instructors and the interpreting students were particularly motivated to explain the interpreter's action space in all its diversity. Two aspects that caused insecurity especially for the interpreting students were the interpreting mode and the appropriate way to render the information into the target language (either preserved or customised). Their behaviour in the first role-play scenarios made it seem as if they were afraid to make decisions on their own (falling into the role of an assistant rather than a professional), waiting instead for instructions from those conducting the questioning. This impression was confirmed in some of the discussions that followed the role-play. In the discussions, the students reflected on the behaviour of both "interpreters" and "legal professionals" in the scenarios and, using the rules of forum theatre, sought solutions that both groups of students were satisfied with. Over time, the two disciplines came to see each other more as partners, which was visible in their cooperation: both groups felt informed about the expectations and requirements of the other and tried to act in a way that would enable the most satisfying communicative situation possible.

\subsection{Feedback and evaluation}

To evaluate the course and its outcomes for the students, the participants were asked to fill in a retrospective feedback questionnaire on the last day of class. It contained questions regarding the structure of the course, its content, the connection between theory and practice, and the interactions with students from the other student group. In addition, the course was evaluated as part of the university's routine evaluation programme, which focuses mostly on the content, workload and organisation of courses.

The results of the feedback questionnaire show that the vast majority of the participants were satisfied with the didactic implementation of the course and the way it connected students across disciplines, made them aware of academic issues in both their own and other fields, and connected academic learning to professional competences (cf. Figures 2-5). The responses to questions related to both subject-related and methodological-operative learning (Figures 2 and 3 ) and socio-communicative subject learning (Figures 4 and 5 ) indicate that the transdisciplinary connected approach was well suited to this course. This is also reflected in one comment taken from an evaluation form, which also touches on affectiveethical learning:

Overall, the class was very practice-oriented and was the first opportunity to use questioning techniques ourselves. [...] Giving life to this subject contributed a lot to the discussion, which is useful to really understand the subject. And not least the cooperation with students of a different subject - understanding where the problems of interpreters lie is something we will surely always remember thanks to the exercises and frank discussions. 
Kadrić, M., Rennert, S., \& Mikić, D. (2021). Connected education and co-construction of knowledge in a joint course for law and interpreting students. Linguistica Antverpiensia, New Series: Themes in Translation Studies, 20, 52-73.

Affective-ethical outcomes are less clearly visible in the questionnaire but some indications of them can be gleaned from Figure 5 and the responses in the open comment field at the end of the questionnaire, such as this:

I find the concept really good, I learned a lot here and made new friendships that I would not have otherwise. An exciting glimpse at legal practice and the life of an interpreter.

\section{Structure and content}

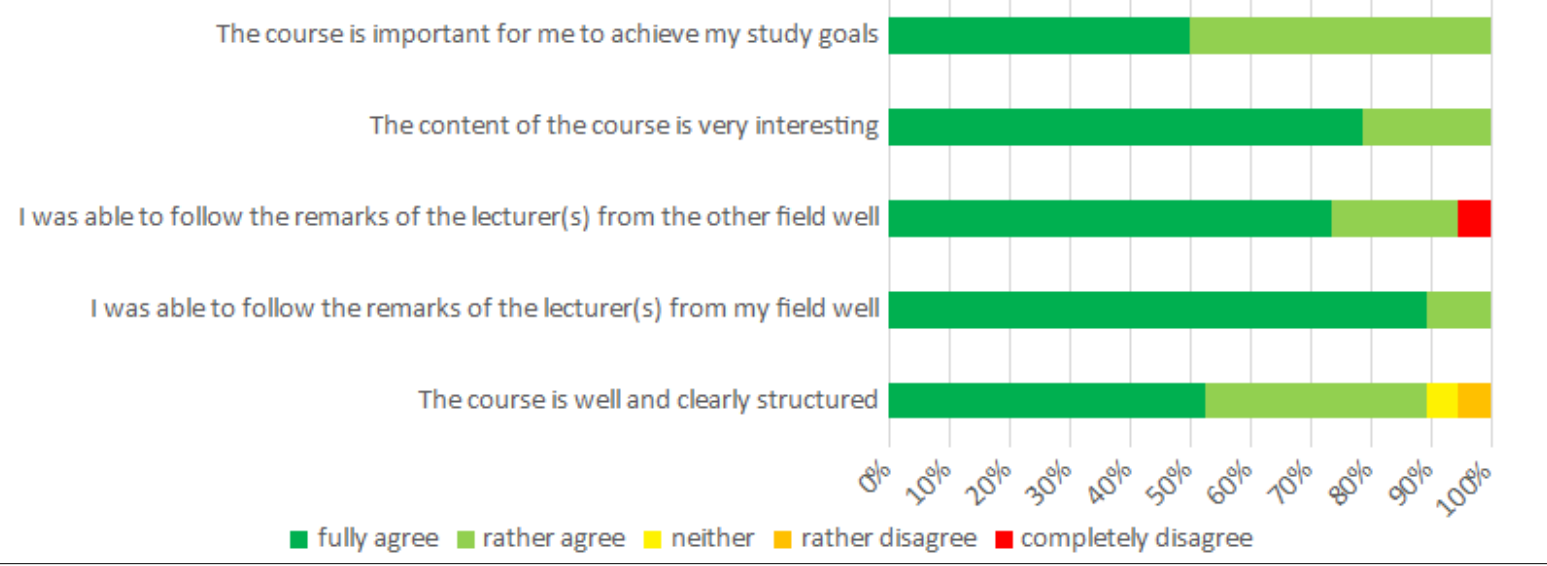

Figure 2: Evaluation - Structure and content

Science and practice

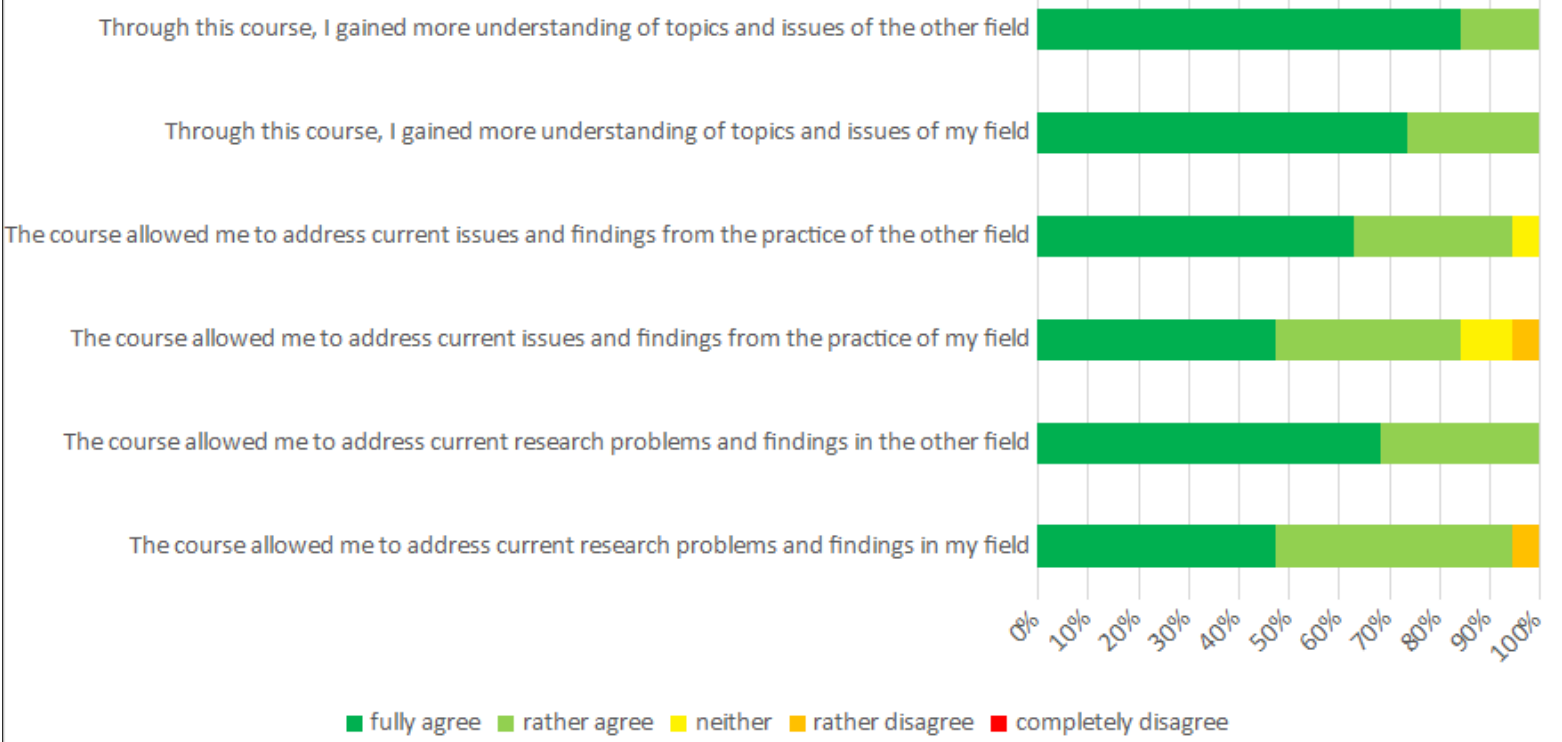

Figure 3: Evaluation - Science and practice 
Kadrić, M., Rennert, S., \& Mikić, D. (2021). Connected education and co-construction of knowledge in a joint course for law and interpreting students. Linguistica Antverpiensia, New Series: Themes in Translation Studies, 20, 52-73.

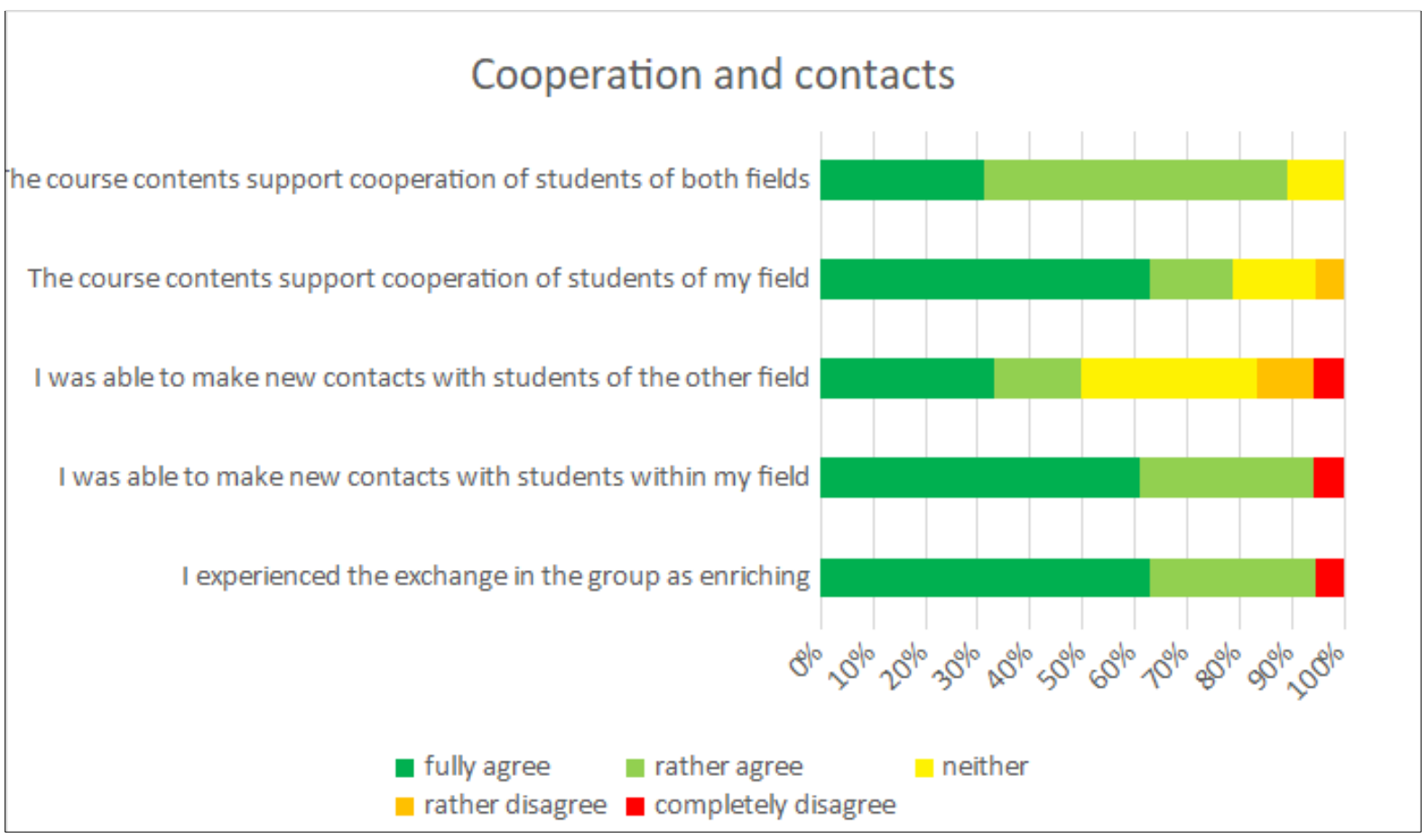

Figure 4: Evaluation - Cooperation and contacts

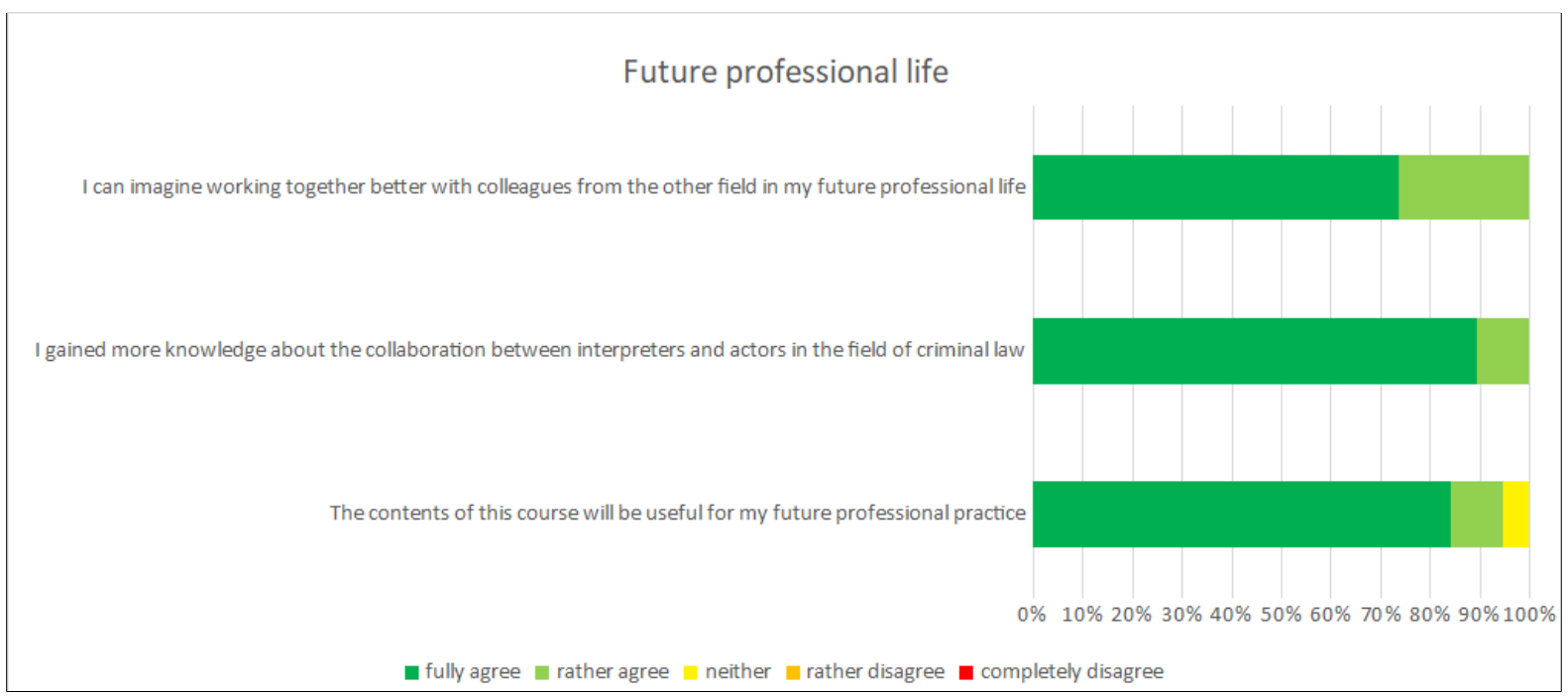

Figure 5: Evaluation - Future professional life

\subsection{Equalisation of professions}

Although it is difficult to delineate didactics clearly, we have tried to draw an outline and have presented some methods that are widely used and recognised. The aim was to enable law students to evaluate the probative value of results in criminological terms and to understand the fundamentals of interpreting so that they might see interpreting as an independent profession rather than as rendering assistance to legal professionals. For their part, the interpreting students gained insights into questioning techniques as used in court proceedings and their psychological and legal limitations and possibilities. Building on this understanding, they could try out different interpreting approaches, test the limits of these 
Kadrić, M., Rennert, S., \& Mikić, D. (2021). Connected education and co-construction of knowledge in a joint course for law and interpreting students. Linguistica Antverpiensia, New Series: Themes in Translation Studies, 20, 52-73.

methods and learn to argue their choices. Furthermore, observation and reflection showed both groups of students to be on an equal footing, with both law and interpreting students taking an active role, whereas initially the interpreting students had tended to wait for instructions from their law counterparts. This development was summed up by one of the participants:

In the final simulation, the interpreters seemed considerably more confident in exercising their tasks compared to the previous practice simulations. They changed places during the trial by themselves when switching between interpreting modes. They also did not hesitate to interrupt proceedings with brief questions or comments if they thought the completeness of the interpretation was at risk. (Final report, student quote)

\section{Conclusion}

Connectedness in higher education and overarching goals means that everyone involved influences the other and has to work in balance. The task is a broad one, one not only focused on the curriculum and answering scientific and technical questions but on promoting the discussion of mutual dependencies and societal needs. Teaching and learning are seen as a process of both knowledge acquisition and development in a future workplace and social context. In the process, students gain an understanding of the theory in their field and also of selected aspects of relevant parts of the connected field.

Transdisciplinary questions and approaches are increasingly becoming a staple in teaching. The results of this joint learning and teaching exercise show that all dimensions of connectivity came together to create an inspiring and motivating learning environment and experience for students. Both groups improved their competences in their own field by working together as equals. Understanding the way the other profession operates and the reasons for their actions, what they can expect from them and what they can ask prepares them for the world of work in a changing landscape. This example of a connected approach shows that it can have benefits for research, teaching and ultimately the workplace, contributing as it does to the equalisation of professions.

\section{References}

Ahrens, B. (2015). Body language. In F. Pöchhacker, N. Grbić, P. Mead, \& R. Setton (Eds.), Routledge encyclopedia of interpreting studies (pp. 36-38). Routledge. https://doi. org/10.4324/9781315678467

Albl-Mikasa, M. (2008). (Non-)sense in note-taking for consecutive interpreting. Interpreting, 10(2), 197-231. https://doi.org/10.1075/intp.10.2.03alb

Andres, D. (2002). Konsekutivdolmetschen und Notation. Lang.

Argyle, M. (2013). Körpersprache \& Kommunikation: Nonverbaler Ausdruck und soziale Interaktion (10th ed.). Junfermann.

Artkämper, H., \& Schilling, K. (2014). Vernehmungen: Taktik - Psychologie - Recht (3rd ed.). VDP.

Bansal, A., Swann, J., \& Smithson, W. H. (2014). Using professional interpreters in undergraduate medical consultation skills teaching. Advances in Medical Education and Practice, 5, 439-450. https://doi.org/10.2147/AMEP.S71332

Barnett, R. (2016). Understanding the university: Institution, idea, possibilities. Routledge. 
Kadrić, M., Rennert, S., \& Mikić, D. (2021). Connected education and co-construction of knowledge in a joint course for law and interpreting students. Linguistica Antverpiensia, New Series: Themes in Translation Studies, 20, 52-73.

Berk-Seligson, S. (1990). The bilingual courtroom: Court interpreters in the judicial process. The University of Chicago Press.

Berk-Seligson, S. (2017). The bilingual courtroom: Court interpreters in the judicial process (2nd ed.). The University of Chicago Press.

Blackledge, A. (2011). Linguistic ethnography. In M. J. Grenfell (Ed.), Bourdieu, language and linguistics (pp. 121-146). Continuum.

Boal, A. (1993). Theatre of the oppressed. Theatre Communications Group.

Creese, A. (2008). Linguistic ethnography. In K. A. King \& N. H. Hornberger (Eds.), Encyclopedia of language and education, Volume 10: Research methods in language and education (pp. 229241). Springer.

Crezee, I. (2015). Semi-authentic practices for student health interpreters. Translation \& Interpreting, 7(3), 50-62. https://doi.org/10.12807/ti.107203.2015.a04

Dam, H. V. (2004). Interpreters' notes. On the choice of language. Interpreting, 6(1), 3-17. https://doi.org/10.1075/intp.6.1.03dam

Evans, J., Shaffer, S., \& Walsh, D. (2020). Interpreters in investigative contexts. In R. Bull \& I. BlandónGitlin (Eds.), The Routledge international handbook of legal and investigative psychology (pp. 133-148). Routledge. https://doi.org/10.4324/9780429326530-10

Ewens, S., Vrij, A., Mann, S., Leal, S., Jo, E., \& Houston, K. (2017). The effect of the presence and seating position of an interpreter on eliciting information and cues to deceit. Psychology, Crime \& Law, 23(2), 180-200. https://doi.org/10.1080/1068316X.2016.1239100

Fung, D. (2017). A connected curriculum for higher education. UCL Press. https://doi.org/10. $14324 / 111.9781911576358$

Gehl, R., \& Plecas, D. (2016). Introduction to criminal investigation: Processes, practices and thinking. Justice Institute of British Columbia.

Gile, D. (2009). Basic concepts and models for interpreter and translator training. John Benjamins. https://doi.org/10.1075/btl.8

González-Davies, M., \& Enríquez-Raído, V. (2016). Situated learning in translator and interpreter training: Bridging research and good practice. The Interpreter and Translator Trainer, 10(1), 111. https://doi.org/10.1080/1750399X.2016.1154339

Grafl, C., \& Stempkowski, M. (2017). Lie to me: Wahrheitsfindung im Spannungsfeld divergierender Interessen. Österreichische Juristen-Zeitung, 2, 62-70.

Hale, S. (2001). How are courtroom questions interpreted?: An Analysis of Spanish interpreters' practice. In I. Mason (Ed.), Triadic exchanges: Studies in dialogue interpreting (pp. 21-50). Routledge.

Hale, S. (2004). The discourse of court interpreting: Discourse practices of the law, the witness, and the interpreter. John Benjamins. https://doi.org/10.1075/btl.52

Hale, S., \& Gibbons, J. (1999). Varying realities: Patterned changes in the interpreter's representation of courtroom and external realities. Applied Linguistics, 20(2), 203-220. https://doi.org/10.1093/applin/20.2.203

Hale, S., \& Gonzalez, E. (2017). Teaching legal interpreting at university level: A research-based approach. In L. Cirillo \& N. Niemants (Eds.), Teaching dialogue interpreting: Research-based proposals for higher education (pp. 200-216). John Benjamins. https://doi.org/10.1075/btl.138.10hal

Hale, S., Goodman-Delahunty, J., \& Martschuk, N. (2019). Interpreter performance in police interviews: Differences between trained interpreters and untrained bilinguals. The Interpreter and Translator Trainer, 13(2), 107-131. https://doi.org/10.1080/1750399X.2018.1541649

Herbert, J. (1968). The interpreter's handbook: How to become a conference interpreter (2nd ed.). Georg. 
Kadrić, M., Rennert, S., \& Mikić, D. (2021). Connected education and co-construction of knowledge in a joint course for law and interpreting students. Linguistica Antverpiensia, New Series: Themes in Translation Studies, 20, 52-73.

Jacobsen, B. (2004). Pragmatic meaning in court interpreting: An empirical study of additions in consecutively interpreted question-answer dialogues. HERMES - Journal of Language and Communication in Business, 17(32), 237-249. https://doi.org/10.7146/hilcb.v17i32.25772

Kadrić, M. (2011). Dialog als Prinzip: Für eine emanzipatorische Praxis und Didaktik des Dolmetschens. Narr.

Kadrić, M. (2014a). Giving interpreters a voice: Interpreting studies meets theatre studies. The Interpreter and Translator Trainer: Special Issue: Dialogue Interpreting in Practice: Bridging the Gap between Empirical Research and Interpreter Education, 8(3), 452-468. https://doi.org/10.1080/1750399X.2014.971485

Kadrić, M. (2014b). Mission impossible? Training for the institutions and educating for society. In C. Falbo \& M. Viezzi (Eds.), Traduzione e interpretazione per la società e le istituzioni (pp. 131142). EUT.

Kadrić, M. (2015). Role play. In F. Pöchhacker, N. Grbić, P. Mead, \& R. Setton (Eds.), Routledge encyclopedia of interpreting studies (pp. 360-361). Routledge.

Kadrić, M. (2017). Make it different!: Teaching interpreting with theatre techniques. In L. Cirillo \& N. Niemants (Eds.), Teaching dialogue interpreting: Research-based proposals for higher education (pp. 276-292). John Benjamins. https://doi.org/10.1075/btl.138.14kad

Kadrić, M. (2019). Gerichts- und Behördendolmetschen: Prozessrechtliche und translatorische Perspektiven. Facultas.

Kadrić, M. (2021). Legal interpreting and social discourse. In M. Ji \& S. Laviosa (Eds.), The Oxford handbook of translation and social practices (pp. 501-520). Oxford University Press. https://doi.org/10.1093/oxfordhb/9780190067205.013.21

Kelly, D. (2010). Curriculum. In Y. Gambier \& L. van Doorslaer (Eds.), Handbook of translation studies (Vol. 1, pp. 87-93). John Benjamins. https://doi.org/10.1075/hts.1.cur1

Klafki, W. (2007). Neue Studien zur Bildungstheorie und Didaktik: Zeitgemäße Allgemeinbildung und kritisch-konstruktive Didaktik (6th ed.). Beltz.

Lai, M., \& Mulayim, S. (2014). Interpreter linguistic intervention in the strategies employed by police in investigative interviews. Police Practice and Research, 15(4), 307-321. https://doi.org/10.1080/15614263.2013.809929

Leins, D. A., Zimmerman, L. A., \& Polander, E. N. (2017). Observers' real-time sensitivity to deception in naturalistic interviews. Journal of Police and Criminal Psychology, 32(4), 319-330. https://doi.org/10.1007/s11896-017-9224-2

Llewellyn-Jones, P., \& Lee, R. G. (2014). Redefining the role of the community interpreter: The concept of role-space. SLI Press.

Luciew, D., Mulkern, J., \& Punako, R. Jr. (2011). Finding the truth: Interview and interrogation training simulations. In Interservice/Industry Training, Simulation, and Education Conference (I/ITSEC): Vol. 2011: Prepare the force... Secure the future. http://www.iitsecdocs.com/volumes/2011

Nord, C. (2009). Textanalyse und Übersetzen: Theoretische Grundlagen, Methode und didaktische Anwendung einer übersetzungsrelevanten Textanalyse (4th ed.). Groos.

Ott, B. (2011). Grundlagen des beruflichen Lernens und Lehrens. Ganzheitliches Lernen in der beruflichen Bildung (4th ed.). Cornelsen.

Prieto-Velasco, J. A., \& Fuentes-Luque, A. (2016). A collaborative multimodal working environment for the development of instrumental and professional competences of student translators: An innovative teaching experience. The Interpreter and Translator Trainer, 10(1), 76-91. https://doi.org/10.1080/1750399X.2016.1154344

Prunč, E. (2019). Entwicklungslinien der Translationswissenschaft: Von den Asymmetrien der Sprachen zu den Asymmetrien der Macht (4th ed.). Frank \& Timme.

Rennert, S. (2021). Qualität als gemeinsame Verantwortung: Aus- und Weiterbildung für DolmetscherInnen und NutzerInnen im Rechtsbereich. In K. Kaindl, S. Pöllabauer, \& D. Mikić 
Kadrić, M., Rennert, S., \& Mikić, D. (2021). Connected education and co-construction of knowledge in a joint course for law and interpreting students. Linguistica Antverpiensia, New Series: Themes in Translation Studies, 20, 52-73.

(Eds.), Dolmetschen als Dienst am Menschen: Texte für Mira Kadrić (pp. 215-228). Narr Francke Attempto.

Rigney, A. C. (1999). Questioning in interpreted testimony. International Journal of Speech Language and the Law, 6(1), 83-108. https://doi.org/10.1558/sll.1999.6.1.83

Skaaden, H. (2013). No set answers?: Facilitating interpreter students' learning in an experiential approach. In C. Wadensjö (Ed.), Training the trainers: Nordic seminar on interpreter education (pp. 11-26). Stockholm: Universitetsservice US-AB.

Soukara, S., Bull, R., Vrij, A., Turner, M., \& Cherryman, J. (2009). What really happens in police interviews of suspects?: Tactics and confessions. Psychology, Crime \& Law, 15(6), 493-506. https://doi.org/10.1080/10683160802201827

Stempkowski, M., \& Grafl, C. (2021). Dolmetschen und Lügenerkennung. In K. Kaindl, S. Pöllabauer, \& D. Mikić (Eds.), Dolmetschen als Dienst am Menschen: Texte für Mira Kadrić (pp. 161-173). Narr Francke Attempto.

The Global Deception Research Team (2006). A world of lies. Journal of Cross-Cultural Psychology, 37(1), 60-74. https://doi.org/10.1177/0022022105282295

TransLaw. (2018-2019). Exploring legal interpreting service paths and transcultural law clinics for persons suspected or accused of crime. TransLaw Research Group. https://trans law.univie.ac.at/activities/translaw-project/

Venuti, L. (2018). The translator's invisibility: A history of translation (2nd ed.). Routledge. https://doi.org/10.4324/9780203553190

Vrij, A. (2005). Criteria-based content analysis: A qualitative review of the first 37 studies. Psychology, Public Policy, and Law, 11(1), 3-41. https://doi.org/10.1037/1076-8971.11.1.3

Vrij, A. (2006). Challenging interviewees during interviews: The potential effects on lie detection. Psychology, Crime \& Law, 12(2), 193-206. https://doi.org/10.1080/10683160512331331319

Vrij, A., \& Mann, S. (2006). Criteria-based content analysis: An empirical test of its underlying processes. Psychology, Crime \& Law, 12(4), 337-349. https://doi.org/10.1080/106831 60500129007

Vrij, A., Leal, S., Mann, S., Fisher, R. P., Dalton, G., Eunkyung, J., Shaboltas, A., Khaleeva, M., Granskaya, J., \& Houston, K. (2018). Using unexpected questions to elicit information and cues to deceit in interpreter-based interviews. Applied Cognitive Psychology, 32(1), 94-104. https://doi.org/10.1002/acp.3382

Vrij, A., Leal, S., Fisher, R. P., Mann, S., Eunkyung, J. Shaboltas, A. Khaleeva, M., Granskaya, J., \& Houston, K. (2019). Eliciting information and cues to deceit through sketching in interpreterbased interviews. Applied Cognitive Psychology, 33(6), 1197-1211. https://doi.org/10.1002/acp.3566

Walklate, S. (2007). Understanding criminology: Current theoretical debates (3rd ed.). McGrawHill/Open UP.

i During the course, questioning was used as a collective term to include all communicative situations in legal settings where legal officials ask individuals questions as part of gathering information and evidence, i.e. interviews, interrogations and hearings, and not only in a police context, where it has a specific meaning (Gehl \& Plecas, 2016).

ii See, e.g., Venuti (2018), Nord (2009), and Berk-Seligson (1990/2017). For an overview of different nomenclature and the underlying concepts, see Kadrić $(2019,2021)$.

iii This blend of interactional analysis and analysis of language is based on the approach of linguistic ethnography (Blackledge, 2011; Creese, 2008). 
Kadrić, M., Rennert, S., \& Mikić, D. (2021). Connected education and co-construction of knowledge in a joint course for law and interpreting students. Linguistica Antverpiensia, New Series: Themes in Translation Studies, 20, 52-73.

iv The Transcultural Law Clinic and research related to it referenced in this article were funded by the European Commission in the project TransLaw (2018-2019), DG Justice; Grant Agreement number: 760157 - TransLaw - JUST-AG-2016/JUST-AG-2016-06.

$v$ It should be noted that this didactic model does not discuss the results of individual studies or the opinions of "practisearchers". Instead, it presents an approach for learners that considers the existing studies (e.g. Albl-Mikasa, 2008; Andres, 2002; Dam, 2004) and has been supplemented by years of action research and didactisation in dialogue interpreting.

vi The right of defence against a criminal accusation includes the possibility of refusing to testify or choosing the line of defence freely - meaning that the defendant is allowed to lie. The situation is different for witnesses, who are legally obliged to give a statement and to tell the truth. Making a false statement as a witness is punishable by imprisonment.

vii We expand on Llewellyn-Jones and Lee's (2014) concept of role-space, using it to refer not only to interpreters but also to all professionals involved.

viii Prunč (2019), who regards interpreting and translation as a cooperative activity, highlights the following areas for developing a new translation culture: cooperation, loyalty, transparency and sustainability. 